\title{
Pengembangan Lembar Aktivitas Matematika Berorientasi Pendekatan Saintifik
}

\author{
Novia Indriani $^{1}$ *, Aan Subhan Pamungkas ${ }^{1}$, Trian Pamungkas Alamsyah ${ }^{1}$ \\ ${ }_{1}^{1}$ Universitas Sultan Ageng Tirtayasa. Jalan Ciwaru Raya No 25 Serang Banten, Indonesia. \\ * Corresponding Author. E-mail: asubhanp@untirta.ac.id
}

\begin{abstract}
Abstrak
Penelitian ini bertujuan untuk mengembangkan lembar aktivitas siswa matematika pada materi volume kubus dan balok, mengetahui kualitas lembar aktivitas matematika yang dikembangkan, mengetahui respon pengguna terhadap lembar aktivitas matematika, serta mengetahui pemahaman siswa setelah menggunakan lembar aktivitas matematika. Metode penelitian pengembangan yang digunakan dalam penelitian ini mengacu pada desain penelitian model 4D yang dikembangkan oleh Thiagarajan yang terdiri dari 4 tahap pengembangan yaitu Define, Design,Develop, dan Disseminate. Subjek penelitian ini adalah 30 siswa kelas V di SDN Panancangan 2. Hasil penelitian adalah (1) rata-rata tingkat kelayakan lembar aktivitas matematika mencapai 84,6\% yang masuk dalam kategori "sangat layak", (2) respon siswa terhadap lembar aktivitas matematika memperoleh rata-rata presentase sebesar $97 \%$ yang termasuk dalam kategori "sangat baik", (3) respon guru terhadap lembar aktivitas matematika memperoleh rata-rata presentase sebesar $83 \%$ yang termasuk dalam kategori "sangat baik" dan (4) Tes Pemahaman siswa memperoleh nilai rata-rata sebesar 86,03 yang menunjukkan pemahaman siswa dalam kategori "sangat baik" sehingga dapat disimpulkan bahwa lembar aktivitas matematika berhasil dikembangkan menjadi bahan ajar yang lebih baik karena telah disusun sesuai dengan perancangan dan mampu memberikan kebermanfaatan bagi pembelajaran.
\end{abstract}

Kata kunci: Lembar Aktivitas Matematika, Pendekatan Saintifik

\begin{abstract}
This research aims to develop mathematics student activity sheets on cube and rectangle box volume material, to determine the quality of mathematicsl activity sheets developed and to find out the user's response to mathematics activity sheets, and to understand students' understanding after using a sheet of mathematics activity. The development research method used in this study refers to the research design of the $4 D$ model developed by Thiagarajan which consists of 4 stages of development namely Define, Design, Develop, and Disseminate. The subjects of this study were 30 fifth grade students at Panancangan Elementary School 2. The results of the study were (1) the average level of feasibility of the mathematics activity sheet reached $84.6 \%$ which was included in the category of "very feasible", obtain an average percentage of $97 \%$ which is included in the category of "very good", (3) the teacher's response to the sheet of mathematics activity gets an average percentage of $83 \%$ which falls into the category of "very good" and (4) understanding test students obtain an average value of 86.03 which shows students' understanding in the "very good" category so that it can be concluded that the mathematics activity sheet was successfully developed into a better teaching material because it has been prepared according to the design and is able to provide learning benefits.
\end{abstract}

Keywords: Student Activity Sheets, Saintific Approach 


\section{PENDAHULUAN}

Proses pembelajaran yang dilakukan di sekolah memegang peranan penting dalam upaya memeroleh pendidikan. Di sekolah dasar, siswa diajarkan berbagai mata pelajaran, salah satunya yaitu matematika. Tujuan akhir pembelajaran matematika sekolah dasar yaitu agar siswa terampil dalam mengaplikasikan berbagai konsep matematika dalam kehidupan seharihari (Heruman, 2007). Untuk mencapai tujuan akhir pembelajaran matematika tersebut, maka guru perlu membuat dan mengembangkan

perencanaan pembelajaran.

Perencanaan pembelajaran memuat perangkat-perangkat pembelajaran yang harus dipersiapkan, antara lain memahami kurikulum, menguasai bahan ajar, menyusun program pembelajaran, melaksanakan program pembelajaran, dan menilai program pengajaran dan hasil proses belajar mengajar yang telah dilaksanakan. Salah satu perangkat yang harus dipersiapkan dalam perencanaan pembelajaran yaitu menguasai bahan ajar. Bahan ajar sebagai salah satu komponen dalam pendidikan yang berpengaruh terhadap mutu pendidikan .Bahan ajar tentunya harus disesuaikan dengan kurikulum yang berlaku. Terlebih saat ini kurikulum yang berlaku yaitu kurikulum 2013 yang mengutamakan pembelajaran berpusat pada siswa dan pendekatan yang diunggulkan dalam kurikulum 2013 ini adalah pendekatan saintifik. Siswa harus secara aktif terlibat dalam pengolahan pengetahuan serta mengembangkan pengetahuan dan keterampilan yang dipelajari. Pembelajaran dengan pendekatan saintifik menekankan pada keterlibatan siswa dalam berbagai aktivitas yang memungkinkan mereka untuk secara aktif mengamati, menanya, mencoba, menalar, dan mengomunikasikan.
Analisis kebutuhan yang dilakukan oleh peneliti dengan memberikan angket kepada guru, memperoleh informasi bahwa bahan ajar yang digunakan pada pembelajaran matematika di sekolah tersebut yaitu hanya dengan menggunakan buku paket. Angket terkait kebutuhan bahan ajar penunjang yang disebar kepada siswa memperoleh hasil bahwa sebanyak 76,7\% siswa memilih LAS sebagai bahan ajar penunjang dalam pembelajaran matematika. Buku paket matematika yang digunakan kurang memfasilitasi siswa dalam proses penemuan konsep matematika. Siswa langsung menerima informasi dari buku paket tersebut tanpa diberi tunjangan dalam mengeksplorasi kemampuannya untuk memperoleh suatu informasi. Berdasarkan permasalahan tersebut, maka diperlukan suatu pengembangan bahan ajar yang dapat memuat aktivitas siswa dalam menemukan konsep matematika yaitu berupa Lembar Aktivitas Siswa (LAS). LAS yang akan dikembangkan tersebut tidak akan berisi materi-materi dan contoh soal, namun akan berisi berbagai aktivitas yang akan mengarahkan pola pikir siswa dalam menemukan suatu konsep pengetahuan.

Berdasarkan beberapa penelitian yang telah dilakukan sebelumnya pengembangan lembar kerja maupun lembar aktivis telah banyak dilakukan (Febriana, Sulur, \& Yudyanto, 2014; Fitriana, Yusuf, \& Susanti, 2016; Pratama \& Prastyaningrum, 2016; Sains \& Purwanto, 2014; Supardi, Rakhmawati, \& Rinaldi, 2018; Susialita, 2016; Utami, Hastuti, Yatimah, Padmini, \& Arroyan, 2013) pendekatan saintifik pun telah banyak digunakan dalam berbagai penelitian (Abduh, 2018; Ali, Sunarno, \& Sukarmin, 2015; Fitriana et al., 2016; Maduretno, Sarwanto, \& Sunarno, 2016; Wahyudi \& Siswanti, 2015). Namun, belum adanya penelitian yang mengembangkan lembar aktivis 
matematika berorientasi pendekatan saintifik untuk siswa SD

Berdasarkan penelitian terdahulu keterbaruan penelitian ini terletak pada pengembangan lembar aktivitas siswa matematika pada materi volume kubus dan balok dengan pendekatan saintifik untuk siswa SD. Maka, tujuan penelitian ini adalah untuk mengetahui kualitas lembar aktivitas matematika yang dikembangkan dan untuk mengetahui respon pengguna terhadap lembar aktivitas matematika, serta mengetahui pemahaman siswa setelah menggunakan lembar aktivitas matematika

\section{METODE PENELITIAN}

Metode penelitian pengembangan yang digunakan dalam penelitian ini mengacu pada desain penelitian model 4D yang dikembangkan oleh Thiagarajan yaitu Define, Design,Develop, dan Disseminate (Trianto, 2014) Subjek penelitian pengembangan LAS matematika berorientasi pendekatan saintifik ini adalah siswa SDN Panancangan 2 yaitu kelas V/C sebanyak 30 siswa. Validasi dinilai dari tiga bagian yaitu validasi materi, validasi bahasa, dan validasi media, para ahli akan menilai LAS matematika yang akan dikembangkan. Validator akan menggunakan lembar angket dalam memvalidasi LAS dan memberi skor untuk setiap item pernyataan. Respon pengguna dinilai oleh guru dan siswa yang akan menilai LAS yang dikembangkan dengan menggunakan angket setelah guru dan siswa melakukan uji coba penggunaan LAS dalam proses pembelajaran.

\section{HASIL DAN PEMBAHASAN}

\section{A. Hasil Penelitian}

Penelitian pengembangan ini menggunakan model 4D yang terdiri dari 4 tahapan, yaitu penetapan (define), perancangan (design), pengembangan (develop), dan penyebaran (disseminate).
Tahapan dalam pengembangan penelitian ini sebagai berikut.

\section{Define}

Kegiatan yang dilakukan pada tahap define adalah kegiatan yang berfokus pada analisis terhadap situasi yang dihadapi guru, karakteristik siswa, dan konsep-konsep yang akan diajarkan. Tahap define dilakukan dengan menganalisis kebutuhan bahan ajar di sekolah, kurikulum, materi, siswa dan merumuskan tujuan. Tahap ini menetapkan syarat-syarat pembuatan bahan-bahan LAS yaitu dengan menganalisa tujuan dan batasan dari materi pembelajaran. Tahapan penetapan dalam pengembangan penelitian ini dilakukan dengan cara:

a. Analisis Kebutuhan

Analisis kebutuhan dilakukan dengan memberikan angket kepada guru dan siswa. Berdasarkan hasil angket tersebut, diperoleh informasi bahwa bahan ajar yang digunakan dalam proses pembelajaran di kelas $\mathrm{V}$ SDN Panancangan 2 yaitu buku paket (Lampiran 1). Proses pembelajaran di SDN Panancangan 2 tidak menggunakan Lembar Aktivitas Siswa (LAS). Guru menyatakan perlu adanya bahan penunjang pembelajaran seperti Lembar Aktivitas Siswa (LAS) pada materi volume bangun ruang dan diharapkan dapat dapat memberikan kemudahan bagi siswa dalam proses pembelajaran serta membantu guru untuk mengoptimalkan proses pembelajaran agar bermakna bagi siswa. Selain itu, siswa juga lebih banyak memilih LAS sebagai bahan ajar penunjang dalam pembelajaran matematika.

b. Analisis Kurikulum

Setelah melakukan analisis kebutuhan, selanjutnya dilakukan analisis kurikulum. Analisis kurikulum yang dilakukan ialah mengidentifikasi kompetensi dasar yang terdapat pada mata pelajaran matematika kelas $\mathrm{V}$ 
dalam Kurikulum 2013. KD yang sesuai dengan materi volume bangun ruang (kubus dan balok) yaitu KD 3.5 Menjelaskan dan menentukan volume bangun ruang dengan menggunakan satuan volume dan KD 4.5 Menyelesaikan masalah yang berkaitan dengan volume bangun ruang dengan menggunakan satuan volume. Kompetensi dasar (KD) 3.5 dijabarkan menjadi beberapa indikator, yaitu mengidentifikasi dan memahami unsurunsur bangun ruang (kubus dan balok), menentukan volume balok dan kubus. Indikator pada kompetensi dasar (KD) 4.5 dijabarkan menjadi menyelesaikan masalah yang berkaitan dengan volume bangun ruang (kubus dan balok) dengan menggunakan satuan volume.

c. Analisis Materi

Analisis materi dilakukan dengan menyesuaikan materi yang terdapat pada Kurikulum 2013. Tujuan dilakukan analisis materi yaitu agar materi dalam LAS sesuai dengan kompetensi dasar yang terdapat pada materi volume bangun ruang (kubus dan balok) dengan subtopik unsur-unsur bangun ruang, volume balok, dan volume kubus yang merupakan indikator pencapaian yang diturunkan dari kompetensi dasar. Analisis materi merajuk pada buku teks yang berjudul "Buku Guru Matematika Kurikulum 2013 untuk SD/MI Kelas V" karangan Anggraena, dkk (2018) dan Indrianti, dkk (2017).

Tujuan pembelajaran dirumuskan dari hasil analisis kebutuhan, kurikulum, dan materi menjadi indikator pencapaian hasil belajar. Tujuan pembelajaran tersebut dapat dirumuskan yaitu sebagai berikut.

1) Siswa dapat mengidentifikasi unsur-unsur bangun ruang (kubus dan balok) dengan baik.

2) Siswa dapat memahami unsurunsur bangun ruang (kubus dan balok) dengan baik.
3) Siswa dapat menentukan volume balok dengan baik.

4) Siswa dapat menentukan volume kubus dengan baik.

5) Siswa dapat menyelesaikan masalah yang berkaitan dengan volume bangun ruang (kubus dan balok) dengan menggunakan satuan volume dengan baik.

d. Analisis Siswa

Analisis siswa dilakukan untuk mengetahui karakteristik siswa yang sesuai dengan rancangan dan pengembangan bahan ajar. Karakterisitik siswa tersebut meliputi latar belakang pengetahuan dan perkembangan kognitif siswa. Pengenalan macam-macam bangun ruang sudah dipelajari oleh siswa saat di kelas 1. Namun, siswa masih banyak yang belum mengenal unsur-unsur apa saja yang terdapat pada bangun ruang, seperti rusuk, sisi, dan titik sudut. Oleh karena itu, LAS yang dikembangkan dimulai dengan pengenalan unsur-unsur bangun ruang. Hal tersebut akan mempengaruhi pengetahuannya terhadap bangun ruang kubus dan balok yang akan dipelajarinya. Banyak ditemui kesalahan konsep yang diketahui oleh siswa tentang sisi dan rusuk. Siswa menganggap bahwa sisi dan rusuk merupakan dua hal yang sama, padahal berbeda.

\section{Design}

Tahap design dilakukan dengan menyusun draft isi LAS matematika yang berorientasi pada pendekatan saintifik. Peneliti menyusun isi LAS tersebut dengan menyesuaikan materi yang telah dianalisis sebelumnya dengan tahapan $5 \mathrm{M}$ yang terdapat pada pendekatan saintifik, yaitu mengamati, menanya, mengumpulkan data, mengasosiasi dan mengomunikasikan.

Materi dibagi menjadi 3 subtopik, yaitu unsur-unsur bangun ruang, balok, dan kubus. Tahapan aktivitas 
Desimal, 2 (2), 2019 - 109

Novia Indriani, Aan Subhan Pamungkas, Trian Pamungkas Alamsyah

disesuaikan dengan tahapan 5M untuk mencapai tujuan pembelajaran pada setiap subtopik dan disertai dengan soal evaluasi untuk mengetahui pemahaman siswa pada subtopik tersebut.

LAS yang dikembangkan berorientasi pada pendekatan saintifik dan memuat 5 tahapan yaitu mengamati, menanya, mengumpulkan data, mengasosiasi dan mengomunikasikan. Aktivitas belajar pada tahapan mengamati yaitu berupa melihat, mengamati, membaca, mendengar, menyimak (tanpa dan dengan alat) hal yang berkaitan dengan materi yang dipelajari. Tahapan mengamati pada LAS materi volume bangun ruang yaitu berupa siswa melihat dan mengamati gambar benda berbentuk kubus dan balok.

Aktivitas belajar pada tahapan menanya yaitu mengajukan pertanyaan dari yang faktual sampai ke yang bersifat hipotesis; diawali dengan bimbingan guru sampai dengan mandiri. Tahapan menanya pada LAS materi volume bangun ruang yaitu berupa penyajian pertanyaan yang mengarah pada hipotesis siswa berdasarkan hal yang telah diamati pada tahapan mengamati sebelunya.

Aktivitas belajar pada tahapan mengumpulkan data (informasi) yaitu menentukan data yang diperlukan dari pertanyaan yang diajukan, menentukan sumber data (benda, dokumen, buku, eksperimen), mengumpulkan data. Tahapan mengumpulkan data (informasi) pada LAS materi volume bangun ruang yaitu berupa penyajian sedikit informasi mengenai materi yang berkaitan dan langkah-langkah percobaan untuk menentukan volume kubus dan balok sebagai langkah untuk menjawab pertanyaan, baik yang disajikan dalam tahapan menanya maupun yang diajukan oleh siswa.

Aktivitas belajar pada tahapan mengasosiasi yaitu menganalisis data dalam bentuk membuat kategori, menentukan hubungan data/kategori, menyimpulkan dari hasil analisis data. Tahapan mengasosiasi pada LAS materi volume bangun ruang yaitu berupa mengaitkan antara hasil pengamatan dengan informasi untuk menjawab kegiatan menanya. Setelah siswa menemukan keterkaitan antar informasi, selanjutnya siswa menyimpulkan hasil dari kegiatan mengumpulkan informasi seperti menyimpulkan tentang cara menentukan volume kubus dan balok.

Aktivitas belajar pada tahapan mengomunikasikan yaitu menyampaikan hasil konseptualisasi dalam bentuk lisan, tulisan, diagram, bagan, gambar, atau media lainnya. Tahapan mengomunikasikan pada LAS materi volume bangun ruang yaitu berupa siswa mempresentasikan kemampuan mereka mengenai apa yang telah dipelajari sementara siswa lain menanggapi. Tanggapan siswa lain bisa berupa saling berkomentar, sanggahan atau dukungan, memberikan usul secara santun. Siswa juga diberi arahan untuk melakukan kunjung karya terkait percobaan membuat kubus dan balok dari kubus satuan yang dilakukan pada tahapan mengumpulkan informasi. Soal evaluasi diberikan pada setiap subtopik pembahasan berupa 5 butir soal essay. Soal essay digunakan untuk mengetahui ketercapaian kemampuan kognitif siswa.

\section{Develop}

a. Validasi Produk

Untuk mengetahui validasi dari segi materi, digunakan instrument validasi uji ahli materi dilihat dari aspek kesesuaian LAS dengan pendekatan saintifik, kualitas isi materi, serta kesesuaian LAS dengan syarat didaktik. Selain itu, validator memberi komentar dan saran untuk perbaikan LAS. Berikut ini hasil validasi ahli materi: 
Desimal, 2 (2), 2019 - 110

Novia Indriani, Aan Subhan Pamungkas, Trian Pamungkas Alamsyah

Tabel 1. Data Validasi Ahli Materi

\begin{tabular}{cccc}
\hline Validator & Skor & Persentase (\%) & Keterangan \\
I & 40 & 80 & Layak \\
II & 38 & 76 & Layak \\
\hline
\end{tabular}

Berdasarkan Tabel 1 kriteria penilaian analisis data validasi ahli materi didapatkan jumlah skor dari validator I sebesar 40 dari jumlah skor maksimal 50 dengan presentase sebesar 80\% masuk pada kriteria "layak" dan jumlah skor dari validator II sebesar 38 dari jumlah skor maksimal 50 dengan presentase sebesar $76 \%$ masuk pada kriteria "layak", sehingga dapat diuji cobakan dengan perbaikan sesuai saran.
Validasi selanjutnya yaitu validasi ahli bahasa. Untuk mengetahui validasi dari segi bahasa, digunakan instrument validasi uji ahli bahasa dilihat dari aspek kesesuaian LAS dengan syarat konstruksi. Selain itu, validator memberi komentar dan saran untuk perbaikan LAS. Berikut ini hasil validasi ahli bahasa pada Tabel 2:

Tabel 2. Data Validasi Ahli Bahasa

\begin{tabular}{cccc}
\hline Validator & Skor & Persentase (\%) & Keterangan \\
I & 44 & 88 & Sangat Layak \\
II & 45 & 90 & Sangat Layak \\
\hline
\end{tabular}

Berdasarkan Tabel 2 kriteria penilaian analisis data validasi ahli bahasa didapatkan jumlah skor dari validator I sebesar 44 dari jumlah skor maksimal 50 dengan presentase sebesar 88\% masuk pada kriteria "sangat layak" dan jumlah skor dari validator II sebesar 45 dari jumlah skor maksimal 50 dengan presentase sebesar $90 \%$ masuk pada kriteria "sangat layak", sehingga dapat diuji cobakan dengan perbaikan sesuai saran.

Validasi selanjutnya yaitu validasi media. Untuk mengetahui validasi dari segi uji media digunakan instrument validasi uji ahli media dilihat dari aspek kesesuaian LAS dengan syarat teknis. Selain itu, validator memberi komentar dan saran untuk perbaikan LAS. Berikut ini hasil validasi ahli media disajikan pada Tabel 3:

Tabel 3. Data Validasi Ahli Media

\begin{tabular}{cccc}
\hline Validator & Skor & Persentase (\%) & Keterangan \\
I & 39 & 86 & Sangat Layak \\
II & 40 & 88 & Sangat Layak \\
\hline
\end{tabular}

Berdasarkan Tabel 3 kriteria penilaian analisis data validasi ahli media didapatkan jumlah skor dari validator I sebesar 39 dari jumlah skor maksimal 45 dengan presentase sebesar 86\% masuk pada kriteria "sangat layak" dan jumlah skor dari validator II sebesar 40 dari jumlah skor maksimal 45 dengan presentase sebesar 88\% masuk pada kriteria "sangat layak", sehingga dapat diuji cobakan dengan perbaikan sesuai saran.

Berdasarkan validasi oleh para ahli tersebut, rata-rata kelayakan produk memperoleh presentase sebesar 84,6\%, maka LAS matematika yang berorientasi 
Desimal, 2 (2), 2019 - 111

Novia Indriani, Aan Subhan Pamungkas, Trian Pamungkas Alamsyah

pada pendekatan saintifik materi volume bangun ruang (kubus dan balok) layak digunakan sebagai bahan ajar penunjang matematika. Kelayakan produk tentunya tidak terlepas dari masukan dan saran dari para ahli.

Ahli materi menyarankan untuk mengubah isi kegiatan 'ayo mengamati' pada aktivitas 2 dan 3, sebelumnya peneliti mencantumkan cara untuk menghitung kubus satuan pada suatu balok atau kubus, namun ahli materi menyarankan agar siswa cukup diminta menghitung banyaknya kubus satuan dari beberapa balok tanpa diberi tahu cara menghitungnya. Hal ini bertujuan untuk mengasah kemampuan siswa dalam menghitung benda yang saling bertumpukan. Hasil perbaikan dari segi materi dapat dilihat pada Gambar 1.

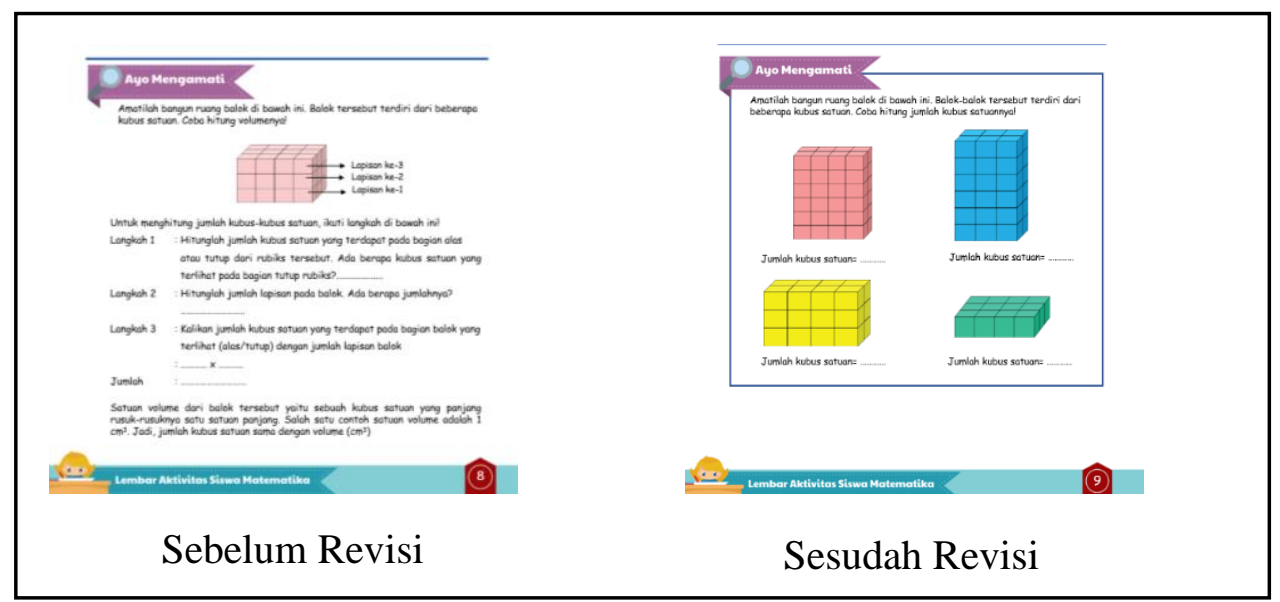

Gambar 1.Revisi Ahli Materi

Ahli bahasa menyarankan untuk menambahkan judul pada setiap subtopik agar bisa lebih memudahkan siswa dalam mengetahui materi apa yang sedang dipelajari. Hasil perbaikan dari segi materi dapat dilihat pada Gambar 2.

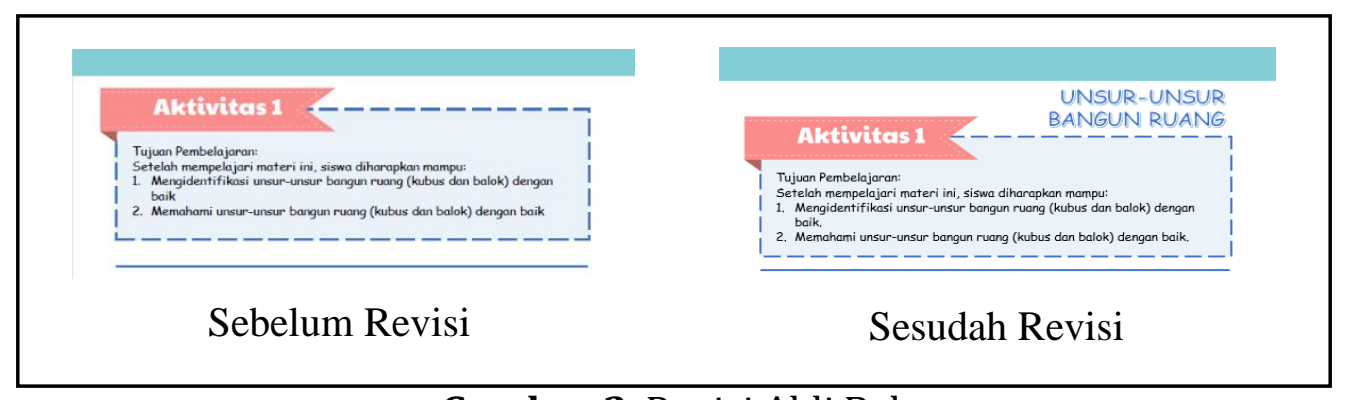

Gambar 2. Revisi Ahli Bahasa 
Novia Indriani, Aan Subhan Pamungkas, Trian Pamungkas Alamsyah

Ahli media menyarankan untuk memvariasikan ukuran font/jenis font agar terlihat lebih menarik. Sebelum adanya revisi, peneliti hanya menggunakan ukuran font yang sama. Setelah revisi, peneliti menggunakan ukuran font yang beragam. Penggunaan ukuran font tersebut disesuaikan dengan keseimbangan dengan gambar, bingkai, dan halaman pada LAS.

Setelah produk sudah divalidasi dan diperbaiki, maka produk layak digunakan untuk dilakukan uji coba lapangan. Uji coba lapangan dilakukan kepada 30 siswa di kelas V/C SDN Panancangan 2. Siswa diberikan angket respon terkait LAS yang telah diuji cobakan pada hari terakhir uji coba setelah pembelajaran berakhir.

\section{Disseminate}

Tahap disseminate merupakan tahap penyebaran produk yang sudah divalidasi dan direvisi serta sudah dianggap layak. Peneliti menyebarkan produk dengan melakukan uji coba lapangan pembelajaran menggunakan LAS matematika yang berorientasi pada pendekatan saintifik materi volume bangun ruang (kubus dan balok). Uji coba lapangan ini untuk mengetahui respon pengguna (1 guru dan 30 siswa) dan pemahaman siswa terhadap penggunaan Lembar Aktivitas Siswa (LAS) yang telah dikembangkan. Uji coba lapangan

a. Respon Siswa

Uji coba lapangan dilakukan kepada 30 siswa di kelas V/C SDN Panancangan 2 selama 2 kali, yaitu pada hari Rabu dan Kamis tanggal 27 dan 28 Februari 2019. Siswa diberikan angket respon terkait LAS yang telah diuji cobakan pada hari terakhir uji coba. Berikut merupakan hasil respon siswa pada Tabel 4:

Tabel 4. Respon Siswa Uji Coba Lapangan

\begin{tabular}{cccc}
\hline Aspek & Materi & Bahasa & Media \\
Skor & 206 & 59 & 144 \\
Persentase (\%) & 98 & 98,30 & 96 \\
Keterangan & Sangat Baik & Sangat Baik & Sangat Baik \\
\hline
\end{tabular}

Berdasarkan respon siswa pada uji coba lapangan, diperoleh hasil respon pada aspek materi sebesar 98\%, aspek bahasa sebesar 98,30\%, dan aspek media sebesar $96 \%$ dimana ketiga aspek tersebut masuk dalam kategori "sangat baik" (Lampiran 10). Data tersebut menunjukkan bahwa respon siswa terhadap LAS matematika yang berorientasi pada pendekatan saintifik materi volume bangun ruang (kubus dan balok) dalam kategori sangat baik dilihat dari aspek materi, bahasa, dan media.

\section{b. Respon Guru}

Angket respon diberikan kepada guru kelas V/C SDN Panancangan 2 untuk mengetahui respon guru terhadap LAS matematika yang berorientasi pada pendekatan saintifik materi volume bangun ruang (kubus dan balok). Berikut merupakan hasil respon guru pada Tabel 5:

Tabel 5. Respon Guru

\begin{tabular}{cccc}
\hline Aspek & Materi & Bahasa & Media \\
Skor & 33 & 34 & 29 \\
Persentase (\%) & 83 & 85 & 81 \\
Keterangan & Sangat Baik & Sangat Baik & Sangat Baik \\
\hline
\end{tabular}




\section{Desimal, 2 (2), 2019 - 113}

Novia Indriani, Aan Subhan Pamungkas, Trian Pamungkas Alamsyah

Berdasarkan data pada Tabel 5 tersebut, diperoleh hasil respon guru pada aspek materi sebesar 83\%, aspek bahasa sebesar 85\%, dan aspek media sebesar 81\% dimana ketiga aspek tersebut masuk dalam kategori "sangat baik" (Lampiran 12). Data tersebut menunjukkan bahwa respon guru terhadap LAS matematika yang berorientasi pada pendekatan saintifik materi volume bangun ruang (kubus dan balok) dalam kategori sangat baik dilihat dari aspek materi, bahasa, dan media. b. Tes Pemahaman

Tes pemahaman diberikan kepada siswa untuk mengukur pemahaman siswa terhadap materi yang terkait setelah mengerjakan Lembar Aktivitas Siswa (LAS) yang dikembangkan oleh peneliti. Tes pemahaman berbentuk 5 soal uraian yang mengacu pada indikator.

Berikut hasil tes pemahaman siswa setelah menggunakan LAS matematika yang berorientasi pada pendekatan saintifik materi volume bangun ruang (kubus dan balok):

Tabel 6. Hasil Tes pemahaman Siswa

\begin{tabular}{cccccc}
\hline Tes Pemahaman & \multicolumn{5}{c}{ Nomor Soal } \\
Skor & $\mathbf{1}$ & $\mathbf{2}$ & $\mathbf{3}$ & $\mathbf{4}$ & $\mathbf{5}$ \\
Nilai Akhir & 89 & 70 & 61 & 82 & 85 \\
Keterangan & 98 & 77 & 67 & 91 & 94 \\
Rata-Rata & Sangat & Baik & Baik & Sangat & Sangat \\
& Baik & & 86,03 & Baik \\
\hline
\end{tabular}

Berdasarkan data pada Tabel 6 tersebut, diperoleh pemahaman siswa setelah menggunakan LAS matematika yang berorientasi pada pendekatan saintifik materi volume bangun ruang (kubus dan balok) dengan nilai rata-rata 86,03 yang menunjukkan pemahaman siswa dalam kategori sangat baik.

\section{B. Pembahasan}

LAS yang dikembangkan berorientasi pada pendekatan saintifik dan memuat 5 tahapan yaitu mengamati, menanya, mengumpulkan data, mengasosiasi dan mengomunikasikan. Tahapan mengamati pada LAS materi volume bangun ruang yaitu berupa siswa melihat dan mengamati gambar benda berbentuk kubus dan balok. Tahapan mengamati mengedepankan pengamatan langsung pada objek yang akan dipelajari sehingga siswa mendapatkan fakta berbentuk data yang objektif yang kemudian dianalisis sesuai dengan tingkat perkembangan siswa. (Hosnan, 2014)
Tahapan menanya pada LAS materi volume bangun ruang yaitu berupa penyajian pertanyaan yang mengarah pada hipotesis siswa berdasarkan hal yang telah diamati pada tahapan mengamati sebelumya. Melalui kegiatan bertanya, siswa dapat mengembangkan rasa ingin tahunya. Menurut Sudirman, metode tanya jawab dapat dijadikan sebagai pendorong dan pembuka jalan bagi siswa untuk mengadakan penelusuran lebih lanjut (dalam rangka belajar) dengan berbagai sumber belajar.(Hosnan, 2014)

Tahapan mengumpulkan data (informasi) pada LAS materi volume bangun ruang yaitu berupa penyajian sedikit informasi mengenai materi yang berkaitan dan langkah-langkah percobaan untuk menentukan volume kubus dan balok sebagai langkah untuk menjawab pertanyaan, baik yang disajikan dalam tahapan menanya maupun yang diajukan oleh siswa. Kegiatan mengumpulkan informasi merupakan tindak lanjut dari kegiatan bertanya. Kegiatan ini dilakukan dengan menggali dan mengumpulkan 


\section{Desimal, 2 (2), 2019 - 114}

Novia Indriani, Aan Subhan Pamungkas, Trian Pamungkas Alamsyah

informasi dari berbagai sumber melalui berbagai cara. Berdasarkan Permendikbud Nomor 81a Tahun 2013, aktivitas mengumpulkan informasi dilakukan melalui eksperimen, membaca sumber lain selain buku teks, mengamati objek/kejadian/aktivitas wawancara dengan narasumber, dan sebagainya.(Hosnan, 2014)

Tahapan mengasosiasi pada LAS materi volume bangun ruang yaitu berupa mengaitkan antara hasil pengamatan dengan informasi untuk menjawab kegiatan menanya. Setelah siswa menemukan keterkaitan antar informasi, selanjutnya siswa menyimpulkan hasil dari kegiatan mengumpulkan informasi seperti menyimpulkan tentang cara menentukan volume kubus dan balok. Berdasarkan Permendikbud Nomor 81a Tahun 2013, mengasosiasi dalam proses pembelajaran adalah memroses informasi yang sudah dikumpulkan, baik terbatas dari hasil kegiatan mengumpulkan/eksperimen maupun hasil dari kegiatan mengamati, menanya dan mengumpulkan informasi. Pengolahan informasi dilakukan untuk menemukan keterkaitan satu informasi dengan informasi lainnya, menemukan pola dari keterkaitan informasi tersebut. Setelah menemukan keterkaitan antar informasi dan menemukan berbagai pola dari keterkaitan tersebut, selanjutnya bersama-sama dalam satu kesatuan kelompok, atau secara individual membuat kesimpulan.(Hosnan, 2014)

Tahapan mengomunikasikan pada LAS materi volume bangun ruang yaitu berupa siswa mempresentasikan kemampuan mereka mengenai apa yang telah dipelajari sementara siswa lain menanggapi. Tanggapan siswa lain bisa berupa saling berkomentar, sanggahan atau dukungan, memberikan usul secara santun. Siswa juga diberi arahan untuk melakukan kunjung karya terkait percobaan membuat kubus dan balok dari kubus satuan yang dilakukan pada tahapan mengumpulkan informasi. Hal ini sesuai dengan yang dikemukakan Majid bahwa pada kegiatan akhir diharapkan siswa dapat mengomunikasikan hasil pekerjaan yang telah disusun baik secara bersama-sama dalam kelompok dan atau secara individu. Kegiatan mengomunikasikan ini dapat diberikan klarifikasi oleh guru agar siswa mengetahui secara benar apakah jawaban yang telah dikerjakan sudah benar atau ada yang harus diperbaiki

Proses pembelajaran memerlukan penilaian karena penilaian berfungsi sebagai alat untuk mengetahui ketercapaian kompetensi siswa dan umpan balik bagi perbaikan proses belajar mengajar. Soal evaluasi diberikan pada setiap subtopik pembahasan berupa 5 butir soal uraian/essay. Penilaian yang cocok untuk meningkatkan kemampuan berpikir siswa adalah soal subyektif berupa uraian/essay, karena soal essay dapat digunakan untuk merangsang siswa untuk belajar mengerti prinsip-prinsip, mengorganisir dan mengintegrasikan ideide, dan menerapkan pengetahuan untuk menyelesaikan masalah (Siswanto, 2006)

Berdasarkan uji coba proses pembelajaran dengan menggunakan LAS matematika yang berorientasi pada pendekatan saintifik materi volume bangun ruang (kubus dan balok), siswa terlihat aktif dalam melakukan aktivitas yang terdapat dalam LAS baik secara individu maupun kelompok. Hal ini juga dibuktikan oleh penelitian yang dilakukan oleh Nurintasari yang menunjukkan bahwa penggunaan LAS dapat memfasilitasi pencapaian keaktifan belajar siswa dalam kategori sangat baik. Berdasarkan hal tersebut dapat disimpulkan bahwa penggunaan LAS dalam pembelajaran dapat mengaktifkan siswa.(Nurintasari, 2015)

Respon siswa terhadap materi (syarat didaktik) LAS matematika yang berorientasi pada pendekatan saintifik materi volume bangun ruang (kubus dan 
balok) sangat baik. Menurut penilaian siswa, kegiatan yang terdapat pada LAS membuat kegiatan belajar lebih terarah, dapat membantu siswa dalam menemukan konsep materi, dan mampu mengembangkan kemampuan matematika siswa, serta mendorong siswa untuk berdiskusi dengan teman-teman yang lain. Hal ini sesuai dengan Darmodjo dan Kaligis bahwa LAS harus menekankan pada proses untuk menemukan konsepkonsep sehingga berfungsi sebagai petunjuk bagi siswa untuk mencari informasi dan bukan alat pemberitahu informasi. LAS yang memenuhi syarat didaktik mampu mengembangkan kemampuan berkomunikasi sosial, emosional, moral, dan estetika pada diri siswa, sehingga tidak hanya ditunjukkan untuk mengenal fakta dan konsep akademis.(Widjajanti, 2008)

Respon siswa terhadap bahasa (syarat konstruksi) LAS matematika yang berorientasi pada pendekatan saintifik materi volume bangun ruang (kubus dan balok) sangat baik. Menurut penilaian siswa, bahasa yang digunakan sederhana dan petunjuk kegiatan dalam LAS jelas sehingga mempermudah siswa dalam melakukan kegiatan pembelajaran. Hal ini sesuai dengan Darmodjo dan Kaligis, bahwa LAS yang memenuhi syarat konstruksi harus menggunakan bahasa yang sesuai dengan tingkat perkembangan siswa. Kalimat yang digunakan sederhana dan pendek, juga komunikatif dan interaktif. Struktur kalimat yang digunakan jelas, memiliki tata urutan pelajaran yang sesuai dengan tingkat kemampuan siswa.(Widjajanti, 2008)

Respon siswa terhadap media (syarat teknis) LAS matematika yang berorientasi pada pendekatan saintifik materi volume bangun ruang (kubus dan balok) sangat baik. Menurut penilaian siswa, tampilan halaman cover dan gambar ilustrasi yang terdapat pada LAS menggunakan pewarnaan yang cerah dan menarik.
Pemilihan jenis huruf mempermudah siswa dalam membaca isi LAS. Selain itu, gambar ilustrasi yang terdapat pada LAS dapat membantu siswa dalam menemukan konsep materi. Hal ini sesuai dengan Darmodjo dan Kaligis, bahwa LAS yang memenuhi syarat teknis yaitu menggunakan huruf yang jelas dibaca meliputi jenis dan ukuran huruf, menyajikan gambar yang mendukung penjelasan konsep, serta memiliki tampilan yang menarik baik isi maupun cover yang meliputi tata letak dan ilustrasi.(Widjajanti, 2008)

Berdasarkan respon siswa pada uji coba lapangan tersebut menunjukkan bahwa respon siswa terhadap LAS matematika yang berorientasi pada pendekatan saintifik materi volume bangun ruang (kubus dan balok) dalam kategori sangat baik dilihat dari aspek materi, bahasa, dan media. Angket respon yang diberikan kepada guru kelas V/C SDN Panancangan 2 untuk mengetahui respon guru terhadap LAS matematika yang berorientasi pada pendekatan saintifik materi volume bangun ruang (kubus dan balok) memperoleh hasil respon juga sangat baik dilihat dari aspek materi, bahasa, dan media.

Nilai rata-rata yang diperoleh siswa setelah dilakukan tes pemahaman untuk mengukur pemahaman siswa setelah menggunakan LAS matematika yang berorientasi pada pendekatan saintifik materi volume bangun ruang (kubus dan balok) yaitu 86,03 yang menunjukkan pemahaman siswa dalam kategori sangat baik. Hal tersebut juga dibuktikan oleh penelitian yang dilakukan oleh Nuintasari yang menunjukkan bahwa penggunaan LAS telah berhasil memfasilitasi pencapaian pemahaman konsep matematika siswa pada pokok bahasan segi empat dengan $81,25 \%$ banyaknya siswa yang mengikuti tes pemahamanmemperoleh skor lebih besar atau sama dengan Kriteria Ketuntasan Minimum (KKM).(Nurintasari, 2015) 
Berdasarkan pembahasan hasil pengembangan LAS matematika yang berorientasi pada pendekatan saintifik materi volume bangun ruang (kubus dan balok), maka bahan ajar tersebut dianggap berhasil dikembangkan menjadi bahan ajar yang lebih baik karena telah disusun sesuai dengan perancangan dan mampu memberikan kebermanfaatan bagi pembelajaran. Sesuai dengan yang dikemukakan oleh Prastowo bahwa tujuan penyusunan LAS yaitu untuk menyajikan bahan ajar yang memudahkan siswa untuk berinteraksi dengan materi yang diberikan, menyajikan tugas-tugas yang meningkatkan penguasaan siswa terhadap materi yang diberikan, melatih kemandirian belajar siswa, dan memudahkan guru dalam memberikan tugas kepada siswa (Prastowo, 2012)

\section{SIMPULAN DAN SARAN}

Berdasarkan hasil penelitian dapat ditarik kesimpulan (1) rata-rata tingkat kelayakan lembar aktivitas matematika mencapai $84,6 \%$ yang masuk dalam kategori "sangat layak", (2) respon siswa terhadap lembar aktivitas matematika memperoleh rata-rata presentase sebesar 97\% yang termasuk dalam kategori "sangat baik", (3) respon guru terhadap lembar aktivitas matematika memperoleh rata-rata presentase sebesar 83\% yang termasuk dalam kategori "sangat baik" dan (4) Tes Pemahaman siswa memperoleh nilai rata-rata sebesar 86,03 yang menunjukkan pemahaman siswa dalam kategori "sangat baik" sehingga dapat disimpulkan bahwa lembar aktivitas matematika berhasil dikembangkan menjadi bahan ajar yang lebih baik karena telah disusun sesuai dengan perancangan dan mampu memberikan kebermanfaatan bagi pembelajaran.

Berdasarkan kesimpulan tersebut, penulis menyarankan bahwa LAS matematika yang berorientasi pendekatan saintifik dapat menjadi salah satu alternative bahan ajar penunjang dalam pembelajaran matematika di kelas V SD untuk membantu siswa dalam memahami materi khususnya untuk materi volume bangun ruang (kubus dan balok) serta bagi peneliti selanjutnya agar dapat mengembangkan LAS dengan materi bangun ruang yang lain seperti prisma, limas, dsb.

\section{DAFTAR PUSTAKA}

Abduh, M. (2018). Interaksi Pada Pendekatan Saintifik ( Kajian Teori Scaffolding ). In Seminar Nasional Pendidikan PGSD UMS \& HDPGSDI Wilayah Jawa.

Ali, M., Sunarno, W., \& Sukarmin. (2015). Pengembangan Modul IPA Berbasis Karakter Islami Melalui Pendekatan Saintifik Pada Tema Rotasi dan Revolusi Bumi Sebagai Implementasi Kurikulum 2013. Jurnal Inkuiri, 4(2), 57-67.

Febriana, L. C., Sulur, \& Yudyanto. (2014). Pengembangan Lembar Kerja Siswa (LKS) Fisika Materi Tekanan Mencakup Ranah Kognitif, Afektif dan Psikomotor Sesuai Kurikulum 2013 untuk Siswa SMP/MTs. Jurnal Universitas Negeri Malang, 2(1), 1-12.

Fitriana, D., Yusuf, M., \& Susanti, E. (2016). Pengembangan Lembar Kerja Siswa Menggunakan Pendekatan Saintifik Untuk Melihat Berpikir Kritis Siswa Materi Perbandingan. Jurnal Pendidikan Matematika, 10(2), 1-17. Heruman. (2007). Model Pembelajaran Matematika di Sekolah Dasar. Bandung: PT Remaja Rosdakarya.

Hosnan, M. (2014). Pendekatan Saintifik dan Kontekstual dalam Pembelajaran Abad 21. Bogor: Penerbit Ghalia Indonesia.

Maduretno, T. W., Sarwanto, \& Sunarno, W. (2016). Pembelajaran IPA Dengan Pendekatan Saintifik Menggunakan Model Learning Cycle dan Discovery Learning Ditinjau Dari Aktivitas Dan 
Motivasi Belajar Siswa Terhadap Prestasi Belajar. JPFK, 2(1), 1-11.

Nurintasari, A. (2015). Pengembangan Lembar Aktivitas Siswa (LAS) Matematika Berbasis Metode Penemuan Terbimbing Untuk Memfasilitasi Pencapaian Pemahaman Konsep dan Keaktifan Belajar Siswa Kelas VII pada Pokok Bahasan Segi Empat. Universitas Islam Negeri Sunan Kalijaga.

Prastowo, A. (2012). Panduan Kreatif Membuat Bahan Ajar Inovatif. Yogyakarta: Diva Press.

Pratama, H., \& Prastyaningrum, I. (2016). Pengaruh Model Pembelajaran Project Based Learning Berbantuan Media Pembelajaran Pembangkit Listrik Tenaga Mikrohidro Terhadap Kemampuan Berpikir Kritis. Jurnal Penelitian Fisika Dan Aplikasinya (JPFA), 6(2), 44-50.

Sains, K. P., \& Purwanto, A. (2014). Implementasi Model Learning Cycle 5E Disertai LKS Untuk Meningkatkan Aktivitas, Keterampilan Proses Sains dan Hasil Belajar Biologi. Jurnal Pendidikan Biologi, 5(1), 1-11.

Siswanto. (2006). Penggunaan Essay dalam Evaluasi Pembelajaran. Jurnal Pendidikan Akutansi Indonesia, 5(1), 57.

Supardi, N., Rakhmawati, R., \& Rinaldi, A. (2018). Lembar Kerja Peserta Didik Berbasis Kegiatan Transaksi Kewirausahaan Materi Sistem Persamaan Linier Dua Variabel. Desimal: Jurnal Matematika, 1(1), 49-55.

Susialita, T. (2016). The Development of Audio-Visual Student Portofolio(LKS) Contextual Teaching And LearningBased (CTL) On Sound Chapter Of Science Suject For Deaf Student. Jurnal Pendidikan IPA Indonesia, 5(2), 192-198.

Trianto. (2014). Mendesain Model Pembelajaran Inovatif, Progesif, dan Kontekstual. Jakarta: Kencana
Prenada Media Group.

Utami, B., Hastuti, B., Yatimah, S., Padmini, S., \& Arroyan, F. (2013). Penerapan Siklus Belajar 5E Disertai LKS Untuk Peningkatan Kualitas Proses dan Hasil Belajar Kimia. Cakrawala Pendidikan, 32(2), 315-325.

Wahyudi, \& Siswanti, M. C. (2015). Pengaruh Pendekatan Saintifik Melalui Model Discovery Learning Dengan Permainan Terhadap Hasil Belajar Matematika Siswa Kelas 5 SD. Scholaria, 5(3), 23-36.

Widjajanti, E. (2008). Kualitas Lembar Kerja Siswa. Yogyakarta: FMIPA UNY. 